However, when all these matters are considered it is still the opinion of the surgeons that surgical practice and the care of the patients was greatly superior to that in the old-style ward. Procedures in vascular surgery that had been discontinued because of the high risk of sepsis in the old accommodation were carried out with relatively good results, and there was much less morbidity and bed loss due to sepsis.

\section{Summary}

In a new surgical ward built in 19621,337 patients were admitted between January 1963 and May 1965, and 988 had operations.

The sepsis rate with Staphylococcus aureus in the patients' wounds was $9 \%, 10 \%$ of the men being infected and $7 \%$ of the women. This compared favourably with the rate of $14 \%$ found in 1962 in an old open ward.

Only $28 \%$ of this sepsis was due to multiple antibioticresistant "hospital" strains, compared with $56 \%$ in the old ward.

There was a reduction in the nasal-carrier rate of hospital strains in patients in the new ward.

There was also a reduction in the amount of staphylococcal contamination of the air and bedding.
Some of the advantages and disadvantages of the design of the new ward as it affected the care of the patients are discussed.

This work was supported in part by à grant from the Nationai Health and Medical Research Council. Our thanks are particularly due to Mrs. Elisabeth Bradshaw for her technical assistance. Miss I. Smyth, ward sister in charge of the old and new ward accommodation, has tolerated with invariable good humour and co-operation the many inconveniences which are an integral part of an investigation of this type.

\section{REFERENCES}

Blair, J. E., and Williams, R. E. O. (1961). Bull. Wld Hlth Org., 24, 771.

Gainsborough, H., and Gainsborough, J. (1964). Principles of Hospital Design. London.

Hurst, V., Grossman, M., Ingram, F. R., and Lowe, A. E. (1958). ₹. Amer. med. Ass., 167, 1223.

Jevons, M. P., and Parker, M. T. (1964). F. clin. Path., 17, 243.

Loewenthal, J. (1962). Brit. med. F., 1, 1437.

May, J., Chalmers, J. P., Loewenthal, J., and Rountree, P. M. (1966). Surg. Gynec. Obstet., 122, 28.

Rountree, P. M., and Beard, M. A. (1962). 7. Hyg. (Lond.), 60, 387. (1965). Med. F. Aust., 1, 498.

Harrington, M., Loewenthal, J., and Gye, R. (1960). Lancet, 2, Loewenthal, J., Tedder, E., and Gye, R.'(1962). Med. F. Aust., 2 , 367.

Rubbo, S. D., and Dixson, S. (1960). Lancet, 2, 394.

\title{
Gastric Mucosa and Susceptibility to Occult Gastrointestinal Bleeding Caused by Aspirin
}

\author{
D. N. CROFT,* D.M., M.R.C.P. ; PHILIP H. N. WOOD, $\dagger$ M.B
}

Brit. med. F., 1967, 1, 137-141

The relation between taking aspirin and the development of gastrointestinal haemorrhage was first recognized by Douthwaite and Lintott (1938). This association has attracted considerable attention, and the subject has been reviewed by Muir (1963a). The occurrence of overt haemorrhage is not directly related to susceptibility to occult bleeding (Parry and Wood, 1963, 1966), a fact probably responsible for much of the confusion on this subject. The two orders of bleeding are best considered separately, and this paper is concerned primarily with the mechanism of occult aspirin bleeding.

Occult blood loss occurs in the majority of people who take repeated doses of aspirin (Stubbé, 1958; Pierson, Holt, Watson, and Keating, 1961 ; Wood, Harvey-Smith, and Dixon, 1962). It is unrelated to dyspepsia caused by aspirin, as the same amount of blood is lost when aspirin is taken on an empty stomach as compared with administration after meals (Wood, 1963 ; Wood and Dixon, 1966), though dyspepsia is much more frequent when the drug is taken on an empty stomach. Furthermore, patients with an active peptic ulcer have been shown not to be unusually susceptible to aspirininduced occult bleeding (Parry and Wood, 1966), even though they readily develop dyspeptic intolerance of the drug (Muir, 1963b) ; similarly, Winkelman and Summerskill (1961) found that aspirin bleeding was unrelated to gastric acid or pepsin secretion.

Gastroscopic observations (Hurst and Lintott, 1939 ; Weiss, Pitman, and Graham, 1961), examination of the stomach after

\footnotetext{
* St. Thomas's Hospital, London, and West Middlesex Hospital, Isleworth. Now Senior Medical Registrar, St. Thomas's Hospital, London. † Postgraduate Medical School of London. Now Senior Research Fellow,
Manchester University Rheumatism Research Centre, Manchester.
}

surgical excision (Muir and Cossar, 1955, 1961), and fractional gastric analysis (Muir and Cossar, 1961) after the administration of single doses of aspirin have indicated that the stomach is the major site of occult bleeding, and this accords with the finding that delayed release of aspirin, as by enteric coating, is associated with a considerable reduction in the volume of blood lost (Stubbé, Pietersen, and van Heulen, 1962 ; Wood and Dixon, 1966).

This report presents three series of observations: (1) a description of the lesions observed in the stomach after repeated doses of aspirin; (2) the variation in susceptibility to occult bleeding between different individuals, and the relation between the degree of susceptibility and quantitative estimates of exfoliation of gastric epithelial cells ; and (3) an analysis of the features of individuals that are relatively insusceptible to aspirin-induced occult bleeding. Taken together these observations enable one to resolve some of the conflicts between previous reports. The data also suggest that lesser degrees of susceptibility to bleeding are sometimes associated with atrophic gastritis, a condition in which there is evidence of an increased turnover of surface epithelial cells (Croft, Pollock, and Coghill, 1966).

\section{Gastrectomy Studies}

Previous direct observations of the human gastric mucosa after aspirin has been taken (Muir and Cossar, 1955, 1961; Weiss et al., 1961) have indicated that a single dose of the drug will cause an erosion in up to $20 \%$ of the subjects studied. The use of a minimal stimulus, a single dose, and 
the necessary choice of a well-characterized lesion have probably determined this relatively low incidence of response.

In contrast, studies of occult bleeding have demonstrated a considerably greater prevalence of response, about $70 \%$ of subjects losing more than $2 \mathrm{ml}$. of blood per day (Pierson et al., 1961; Wood et al., 1962). The disparity may be due partly to the greater sensitivity of the techniques for estimating occult blood, but most investigators have also used repeated doses of aspirin.

\section{Observations}

In order to determine whether repeated doses of aspirin would produce a greater incidence of macroscopic lesions in the stomach, ten patients were studied at the time they underwent partial gastrectomy. The pertinent clinical features of these patients are set out in Table I. Five were given 3-4 g. of soluble aspirin daily in divided doses for two to five days before operation, and the surgical specimens were compared with those from five patients who did not receive aspirin preoperatively. The specimens were examined immediately after removal by being opened along the greater curvature and stretched on a cork mat. The mucosa was inspected macroscopically for erosions, and then was drawn and photographed.

TABLe I.-Clinical Features of Ten Patients Undergoing Partial

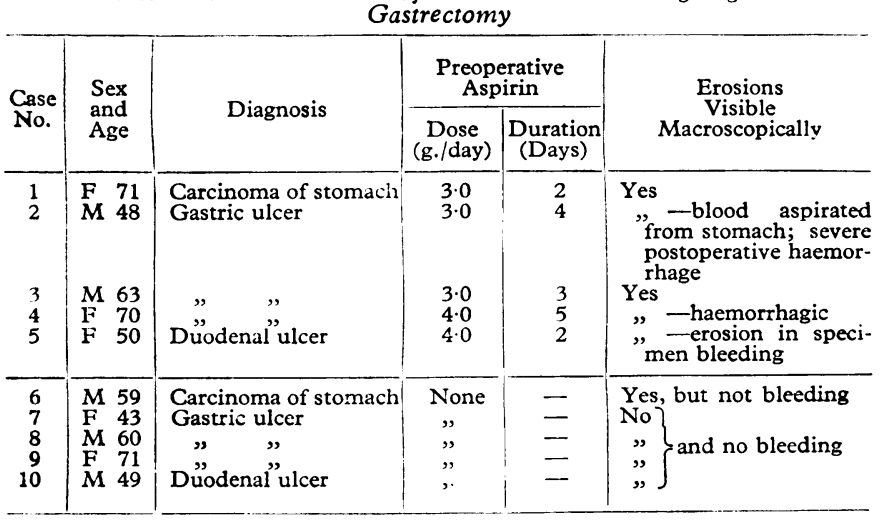

Of the five patients who did not receive aspirin, only the one with a carcinoma showed erosions of the gastric mucosa, whereas erosions were seen in all the patients who had taken aspirin. The erosions varied in number from one to five, and were situated mainly along the lesser curvature. They were usually circular, and were often joined by linear cracks in the mucosa that were apparent only when the specimen was stretched flat. Frank haemorrhage was observed from some of the lesions. When the specimen was scraped to obtain epithelial cells for cytological examination it was noted that the mucosa stripped readily, whereas the superficial layers were much tougher in the patients who had not received aspirin.

Microscopical examination showed that the erosions commonly penetrated the muscularis mucosae. They were surrounded by haemorrhagic zones, and blood vessels were noted at the base of the lesions.

One patient (Case 2) developed a severe postoperative haemorrhage, requiring transfusion of 11 pints (6.25 litres) of blood. As his gastric ulcer had been removed, it seemed probable that erosions in the remaining part of the stomach were bleeding, and that aspirin was the likeliest cause of these erosions. Because of this it was decided to discontinue giving patients aspirin before partial gastrectomy.

Earlier studies of gastrectomy specimens (Muir and Cossar, 1955,1961 ) had suggested that single doses of soluble aspirin were less likely than plain aspirin to cause recognizable lesions in the stomach. The patients in the present series were all given tablets of soluble aspirin dispersed in water, and lesions were seen in all. This accords with the fact that soluble aspirin causes as much occult bleeding as tablets of aspirin, B.P. (Stubbé et al., 1962 ; Wood et al., 1962).

\section{Occult Bleeding}

\section{Observations}

The variation in susceptibility to occult bleeding caused by aspirin is depicted in the Chart, which shows the response of 226 subjects who had no known upper gastrointestinal tract.

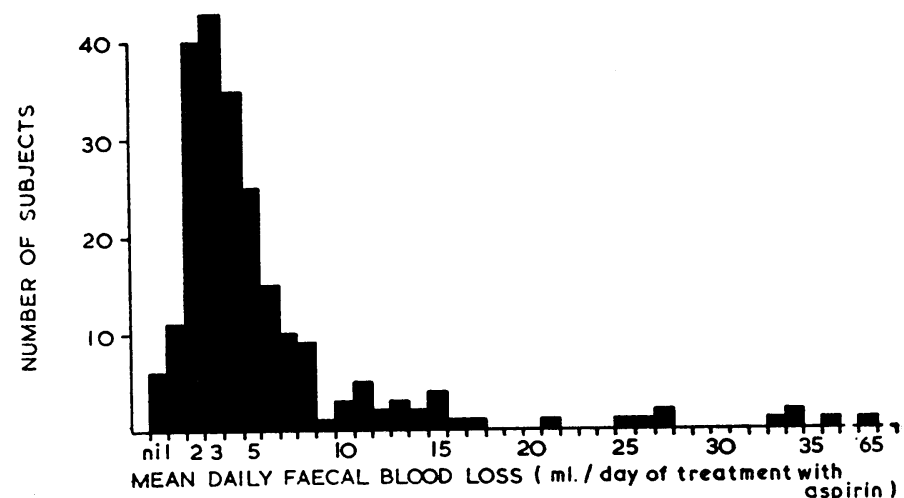

Mean faecal blood loss after aspirin in 226 subjects with no known upper gastrointestinal tract lesion; most gave no history of dyspepsia, and the remainder had had a barium-meal examination that was normal.

lesion; most gave no history of dyspepsia and the remainder had had a barium-meal examination that was normal. Occult blood loss attributable to aspirin was determined by a standard technique (Wood et al., 1962) in which ${ }^{51} \mathrm{Cr}$-labelling of the patient's erythrocytes was used. The subjects were mainly patients attending hospitals in London, but the variation in bleeding between individuals corresponded closely to that seen in normal volunteers in New York City (Pierson et al., 1961). If a loss of more than $2 \mathrm{ml}$./day of treatment is taken as constituting significant blood loss, $78 \%$ of this group showed a positive response, which resembles the prevalence of bleeding determined by benzidine tests in patients attending a hospital in the Netherlands (Stubbé et al., 1962).

The significance of these observations is affected by the reproducibility of the response. Twenty-one subjects were given the same aspirin preparation again between three and ten weeks later. The mean blood loss was $6.3 \mathrm{ml}$./day of treatment in the first study and $6.5 \mathrm{ml}$./day in the second study (mean difference, $0.19 \pm 0.37 \mathrm{ml}$., $\mathrm{P}>0.6$ ). Thus, although subjects varied widely, some showing no bleeding and others losing more than $20 \mathrm{ml}$. of blood per day, the individual's response was consistent. This suggests that susceptibility is determined by factors specific to the particular individual. Analysis of the results in the whole group according to age, sex, and clinical diagnosis failed to reveal any significant difference in susceptibility attributable to these factors.

In the rest of this paper subjects are designated as insusceptible, or non-bleeders, if they lost $2 \mathrm{ml}$. or less per day of treatment, and as susceptible, or aspirin bleeders, if they lost more than $2 \mathrm{ml}$. of blood per day.

\section{Exfoliation of Gastric Epithelial Cells}

The high incidence of erosions in gastrectomy specimens suggested that aspirin might cause excessive exfoliation of gastric epithelial cells. This was confirmed by the increased number of epithelial cells and nuclei seen in gastric washings obtained after the administration of dispersions of soluble 
aspirin, and led to the development of a technique for studying cellular exfoliation after aspirin in a quantitative manner by estimating the deoxyribonucleic acid (D.N.A.) content of gastric washings (Croft, 1963 ; Croft and Lubran, 1965). As the duration of the washouts varied, the values of D.N.A. content were converted into rates of accumulation of D.N.A.

\section{Observations}

The rate of accumulation of D.N.A. in gastric washings was studied in 15 patients in whom aspirin-induced occult bleeding had been studied previously, and the results are presented in Table II. The resting (pre-aspirin) D.N.A. accumulation rate was more than $50 \mu \mathrm{g}$. atoms of D.N.A.-P per minute in six of the eight non-bleeders, whereas it exceeded this value in only two of the seven bleeders. However, the mean rates in the two groups were not significantly different (101.5 and $55.5 \mu \mathrm{g}$. atoms of D.N.A.-P per minute respectively, $\mathrm{P}>0.1$ ). After aspirin an increase in the rate of accumulation of D.N.A. was seen in all except one of the aspirin bleeders, but in only three of the non-bleeders; the remaining non-bleeders all showed a decrease in the rate.

The last washout specimen after aspirin was submitted to cytological examination. There was a difference between aspirin bleeders and those who were insusceptible (Table II). In most of the latter there were no normal gastric epithelial cells, but large numbers of abnormal gastric cells or nuclei and of inflammatory cells were seen. In contrast, in most of the aspirin bleeders the aspirates contained many normal gastric epithelial cells and nuclei, and few abnormal gastric cells or inflammatory cells.

The cytological abnormalities observed in most of the patients who were insusceptible to aspirin-abnormal epithelial cells and the presence of inflammatory cells-are characteristic of atrophic gastritis (Gibbs, 1964). This diagnosis was confirmed by gastric suction biopsy in two patients. A single biopsy specimen had a normal appearance in a third patient (Case 13), but his washings contained both normal and abnormal epithelial cells, suggesting patchy changes in the mucosa. On the other hand, atrophic gastritis was seen in a biopsy specimen from one patient who did show blood loss after aspirin, though her D.N.A. response was similar to that seen in most non-bleeders.

\section{Factors Affecting Susceptibility to Bleeding}

Though the associations described were not uniform, they suggested that those patients who were insusceptible to

TABLE II.-Clinical Features of 15 Patients in Whom Aspirin Bleeding and Gastric D.N.A. Accumulation were Studied

\begin{tabular}{|c|c|c|c|c|c|c|c|c|c|c|}
\hline \multirow{3}{*}{$\begin{array}{l}\text { Case } \\
\text { No. }\end{array}$} & \multirow{3}{*}{\multicolumn{2}{|c|}{$\begin{array}{l}\text { Sex and } \\
\text { Age }\end{array}$}} & \multirow{3}{*}{ Diagno: } & \multirow{3}{*}{$\begin{array}{l}\text { Aspirin } \\
\text { Bleeding } \\
\text { (ml./day of } \\
\text { Treatment) }\end{array}$} & \multicolumn{3}{|c|}{ Rate of Accumulation of D.N.A. } & \multicolumn{2}{|c|}{$\begin{array}{l}\text { Assessment of Cytology of Second } \\
\text { Gastric Washout after Aspirin }\end{array}$} & \multirow{3}{*}{$\begin{array}{l}\text { Gastric } \\
\text { Biopsy }\end{array}$} \\
\hline & & & & & $\begin{array}{l}\text { Before } \\
\text { Aspirin }\end{array}$ & $\begin{array}{l}\text { After Second } \\
\text { Dose of Aspirin }\end{array}$ & \multirow{2}{*}{$\begin{array}{c}\text { Change } \\
\text { after } \\
\text { Aspirin } \\
(\%)\end{array}$} & $\begin{array}{l}\text { Normal Gastric } \\
\text { Epithelial Cells } \\
\text { and Nuclei }\end{array}$ & $\begin{array}{c}\text { Abnormal Cells } \\
\text { and Inflammatory } \\
\text { Cells }\end{array}$ & \\
\hline & & & & & \multicolumn{2}{|c|}{ ( $\mu$ g. atoms D.N.A.-P/min.) } & & \multicolumn{2}{|c|}{$\begin{array}{l}\text { (Proportion of Different Sorts of } \\
\text { Cells in Each Specimen; Total } \\
\text { Cell Content }=3 \text { ) }\end{array}$} & \\
\hline $\begin{array}{l}1 \\
2 \\
3 \\
4 \\
5 \\
6 \\
7\end{array}$ & $\begin{array}{l}\mathbf{P} \\
\mathbf{P} \\
\mathbf{F} \\
\mathbf{P} \\
\mathbf{P} \\
\mathbf{M} \\
\mathbf{F}\end{array}$ & $\begin{array}{l}53 \\
58 \\
42 \\
39 \\
51 \\
41 \\
59\end{array}$ & $\begin{array}{l}\text { Osteoarthrosis } \\
\text { Rheumatic heart disease } \\
\text { Hypochromic anaemia } \\
\text { Rheumatoid arthritis } \\
\text { Thenar wasting (trauma) } \\
\text { Rheumatoid arthritis, D.U. } \\
\text { Hypochromic anaemia }\end{array}$ & $\begin{array}{r}36 \\
21 \\
13 \\
10 \\
9 \\
6 \\
5\end{array}$ & $\begin{array}{c}14 \\
64 \\
20 \\
49 \\
152 * \\
46 \\
44\end{array}$ & $\begin{array}{r}131 \\
137 \\
98 \\
289 \\
231 \\
175 \\
36\end{array}$ & $\begin{array}{l}+835 \\
+114 \\
+390 \\
+490 \\
+52 \\
+380 \\
-18\end{array}$ & $\begin{array}{c}+++ \\
++ \\
0 \\
++ \\
++ \\
++ \\
+t\end{array}$ & $\begin{array}{c}0 \\
0 \\
++ \\
+ \\
0 \\
+ \\
+\end{array}$ & $\begin{array}{l}\text { Not done } \\
\text { ”, ” } \\
\Longrightarrow, \\
\text { "’ ", } \\
\text { Atrophic gastritis }\end{array}$ \\
\hline $\begin{array}{r}8 \\
9 \\
10 \\
11 \\
12 \\
13 \\
14 \\
15\end{array}$ & $\begin{array}{l}\mathbf{M} \\
\mathbf{P} \\
\mathbf{F} \\
\mathbf{F} \\
\mathbf{M} \\
\mathbf{M} \\
\mathbf{F} \\
\mathbf{M}\end{array}$ & $\begin{array}{l}37 \\
52 \\
62 \\
44 \\
45 \\
39 \\
49 \\
67\end{array}$ & $\begin{array}{l}\text { Duodenal ulcer } \\
\text { Rheumatoid arthritis }\end{array}$ & $\begin{array}{l}2 \\
1 \\
1 \\
1 \\
1 \\
0 \\
0 \\
0\end{array}$ & $\begin{array}{r}31 \\
62 \\
46 \\
129 \\
97 \\
143 \\
252 \\
53\end{array}$ & $\begin{array}{r}168 \\
124 \\
72 \\
53 \\
\ddagger \\
61 \\
250 \\
37\end{array}$ & $\begin{array}{r}+425 \\
+100 \\
+57 \\
-59 \\
-57 \\
-1 \\
-30\end{array}$ & $\begin{array}{c}+++ \\
+++ \\
0 \\
0 \\
(0) \\
+ \\
0 \\
0\end{array}$ & $\begin{array}{c}0 \\
0 \\
+++ \\
+++ \\
(+++) \\
++ \\
+++ \\
+++\end{array}$ & $\begin{array}{l}\text { Not done } \\
\text { " " } \\
\text { Atrophic gastritis } \\
\text { Normal " } \\
\text { Not done } \\
\text { "," }\end{array}$ \\
\hline
\end{tabular}

- This patient had an upper respiratory infection at the time gastric washouts were studied. Swallowed secretions may have contributed to the high resting rate of .N.A. accumulation, and in turn may have reduced the percentage increase after aspirin.

The gastric washouts after aspirin were unsuitable for cytological examination.
\$ The rate of accumulation of D.N.A. was measured by a modified technique (Croft and Lubran, 1965), and no aspirin was given. The cytological appearances were those seen after continuous perfusion with $1,500 \mathrm{ml}$. saline.

TABLr III.-Susceptibility to Aspirin-induced Occult Bleeding. A, According to Blood Group, and B-D, in Patients with Various Abnormalities of the Gastrointestinal Tract

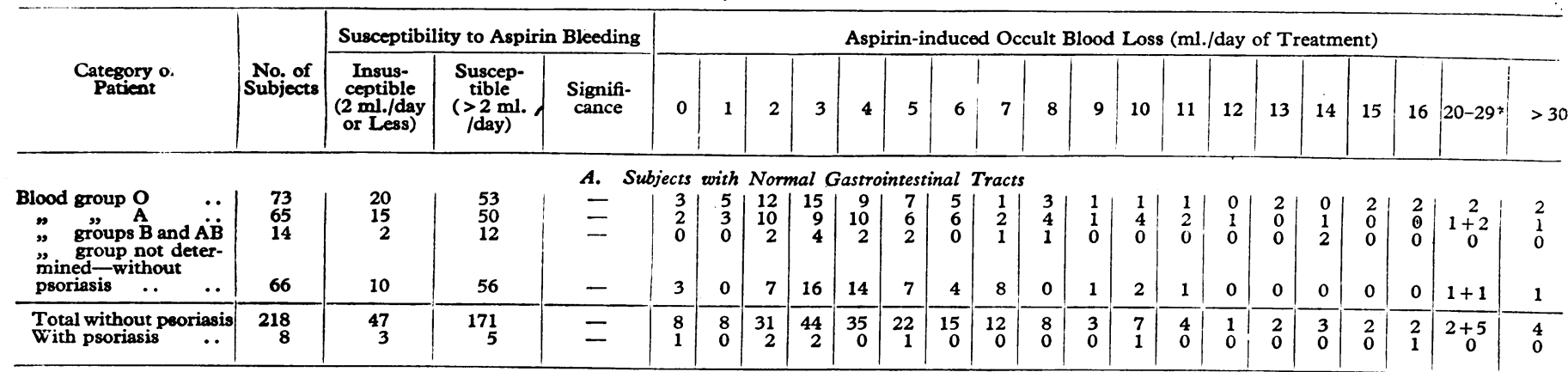

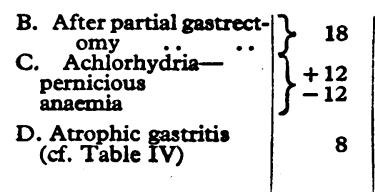

Subjects with Gastrointestinal Abnormalities 
aspirin-induced occult bleeding and those who had atrophic gastritis might be worthy of further study.

\section{Subjects with a Normal Gastrointestinal Tract}

Gastric mucus production has been related to blood group and secretor status, and so the 226 subjects shown in the Chart were reviewed from this point of view. Table III A sets out an analysis of susceptibility to occult bleeding in the 152 patients in whom the blood group had been determined; there is no obvious association between any of these characteristics. There was a suggestion that patients with psoriasis might differ slightly, and so they are shown separately and are excluded from comparisons made with patients having abnormalities of the gastrointestinal tract.

\section{Patients with Abnornalities of the Gastrointestinal Tract}

Occult-bleeding studies had been carried out on 177 subjects having a variety of abnormalities of the gastrointestinal tract, and the records of these patients were reviewed to see whether insusceptibility was associated with any of these abnormalities.

1. Removal of Part of the Stomach.-Eighteen patients who had previously undergone partial gastrectomy had been studied (Table III B), but the variation in susceptibility to aspirin resembled that seen in the normal subjects. Two patients were studied both before and 18 months after partial gastrectomy, but their occult-bleeding susceptibility was unaltered.

2. Innervation of Stomach.-One patient was studied both before and two years after undergoing vagotomy, and her susceptibility to bleeding was unaltered. Similarly, autonomic ganglion or vagal blockade with pempidine and atropine did not affect the susceptibility of another patient.

3. Achlorhydria.-Fractional gastric analysis had been carried out at some time on 24 patients, and had been reported as showing achlorhydria. This was not a very homogeneous group, because a variety of techniques of histamine stimulation had been used, but insusceptibility was observed more often than among the 218 patients with a normal gastrointestinal tract who did not have psoriasis. This difference (Table III C) was more pronounced in patients who did not have pernicious anaemia, $50 \%$ of whom were insusceptible, than in those who did have this condition, one-third of whom were non-bleeders.

4. Atrophic Gastritis.-Eight patients had previously had gastric biopsies taken that showed various grades of atrophic gastritis (Williams et al., 1957). Four patients were nonbleeders (Table III D), and four were aspirin-induced bleeders, though they did not show evidence of enhanced susceptibility to aspirin. Further details of these patients are set out in Table IV.

TABLE IV.-Clinical Features of Eight Patients with Abnormal Gastric Biopsies Whose Susceptibility to Aspirin-induced Occult Bleeding Had Been Determined

\begin{tabular}{|c|c|c|c|c|c|c|}
\hline \multirow[b]{2}{*}{$\begin{array}{l}\text { Case } \\
\text { No. }\end{array}$} & \multirow{2}{*}{$\begin{array}{l}\text { Sex } \\
\text { and } \\
\text { Age }\end{array}$} & \multirow[b]{2}{*}{ Diagnos1: } & \multirow{2}{*}{$\begin{array}{c}\text { Aspirin } \\
\text { Bleeding } \\
\text { (ml./day } \\
\text { of } \\
\text { Treat- } \\
\text { ment) }\end{array}$} & \multirow{2}{*}{$\begin{array}{c}\text { Maximal } \\
\text { Histamine } \\
\text { Stimulation } \\
\text { Test* } \\
\text { (Lowest } p H \\
\text { Recorded) }\end{array}$} & \multicolumn{2}{|c|}{ Gastric Biopsies } \\
\hline & & & & & No. & $\begin{array}{l}\text { Grade of } \\
\text { Atrophic } \\
\text { Gastritist }\end{array}$ \\
\hline $\begin{array}{l}1 \\
2 \\
3 \neq \\
4 \ddagger\end{array}$ & $\begin{array}{ll}F & 39 \\
F & 49 \\
M & 45 \\
F & 44\end{array}$ & $\begin{array}{l}\text { Hypochromic anaemia } \\
\text { "” } \\
\text { Non-ulcer dyspepsia } \\
\text { Hypochromic anaemia }\end{array}$ & $\begin{array}{l}1 \\
1 \\
1 \\
1\end{array}$ & $\begin{array}{l}7 \cdot 0 \\
6 \cdot 8 \\
6 \cdot 9 \\
2 \cdot 0\end{array}$ & $\begin{array}{l}4 \\
2 \\
2 \\
4\end{array}$ & $\begin{array}{l}\text { III } \\
\text { III } \\
\text { I and II } \\
\text { I and II }\end{array}$ \\
\hline $\begin{array}{l}5 \\
6 \\
7 \ddagger \\
8\end{array}$ & $\begin{array}{ll}M & 53 \\
F & 50 \\
F & 59 \\
\text { F } & 44\end{array}$ & $\begin{array}{cc}\text { Hypochromic anaemia } \\
" & " \\
" & "\end{array}$ & $\begin{array}{l}4 \\
5 \\
5 \\
9\end{array}$ & $\begin{array}{l}\text { Not done } \\
6 \cdot 6 \\
2 \cdot 2 \\
1.9\end{array}$ & $\begin{array}{l}2 \\
4 \\
5 \\
2\end{array}$ & II and III \\
\hline
\end{tabular}

Kay (1953).

$\ddagger$ These patients appear in Table II as Cases 12,11, and 7 respectively.

\section{Comments}

Cytological and biochemical evidence (Croft, 1963) indicates that aspirin causes exfoliation of surface cells from normal gastric mucosa. Epithelial exfoliation of this type has been thought to be the "normal physiological response to mild irritation" (Hollander, Stein, and Lauber, 1946). There is a constant renewal of epithelial cells in the human stomach (Lipkin, Sherlock, and Bell, 1963 ; Croft et al., 1966), and presumably this is capable of preserving mucosal integrity under most circumstances.

The gastrectomy data demonstrate that repeated doses of aspirin cause mucosal erosions, which in turn may cause loss of blood. Such impairment of mucosal integrity could result from aspirin stimulating epithelial shedding in excess of the mucosa's ability to replace the surface cells. If this supposition is correct such a sequence of changes must be presumed to occur when the majority of people take repeated doses of aspirin by mouth. Occult bleeding caused by aspirin must then be regarded as an extension of a physiological response by the stomach, and should be evaluated only on the basis of its significance to the individual, such as in contributing to the development of anaemia.

The first test of such a hypothesis is to see whether it can take account of the minority of subjects who show no bleeding after aspirin. It is interesting that most patients who were insusceptible had a higher resting (pre-aspirin) rate of accumulation of D.N.A. than did the aspirin bleeders, and they did not increase exfoliation after taking the drug. This suggests that their gastric epithelium may have been in a maximally dynamic state, and that this conferred some protection against irritants.

The cytological features of most of the insusceptible patients were suggestive of atrophic gastritis, and this was confirmed by biopsy in two patients. A high turnover of the surface epithelium has been demonstrated in patients with this condition (Croft et al., 1966), which would lend support to this concept. Thus mucosal overactivity may protect against local irritants such as aspirin. The considerable variation in the magnitude of occult bleeding caused by aspirin could be related to quantitative differences in the rate of production of epithelial cells.

The inconsistencies in the data also require consideration. Atrophic gastritis is commonly asymptomatic, and therefore may have been present in some of the insusceptible patients who were regarded as having a normal gastrointestinal tract. Furthermore, atrophic changes may sometimes have a patchy distribution, which could cause additional variability in response. Finally, there may be variations in the turnover in mucosa that appears normal histologically.

On the other hand, other factors may have an equally important role. Achlorhydria may play some part independent of the presence of atrophic gastritis, and the evidence is insufficient to determine whether this might be the case. Aspirin may affect the production of mucus (Menguy and Masters, 1965), though to the extent that the latter is reflected by blood groups the present data do not suggest that this is important. It is also possible that in atrophic gastritis the surface cell may be altered so that it is insusceptible to the action of aspirin.

\section{Summary}

The study of gastrectomy specimens obtained after the administration of repeated doses of aspirin suggests that the drug causes erosions, and that the previously reported inconsistencies in the incidence of haemorrhagic lesions were largely a function of dosage. 
Studies of occult bleeding caused by aspirin show that more than $70 \%$ of 226 subjects responded by losing more than $2 \mathrm{ml}$. of blood per day of treatment. There seems to be some protection against this response in patients with atrophic gastritis.

The rate of accumulation of D.N.A. in gastric washings has been used as an index of exfoliation of gastric epithelial cells. The rate of loss of these cells is increased by aspirin in those subjects known to bleed after the drug. It is suggested that a haemorrhagic lesion may result when the rate of loss of surface cpithelial cells exceeds the rate at which they can be replaced.

In some patients with atrophic gastritis a high turnover of gastric epithelial cells may prevent the formation of erosions after taking aspirin.

We are indebted to Dr. Brian Creamer for initiating much of this work ; to Dr. N. F. Coghill for much help and advice; to Mrs. E. B. Skinner and Miss Pamela Coates for technical assistance; and to the subjects who kindly co-operated in this study. We also wish to acknowledge grants from St. Thomas's Hospital Endowment Fund and from the Medical Research Council (D. N. C.), and from the Nicholas Research Institute (P. H.N.W.).

\section{REFERENCES}

Croft, D. N. (1963). Brit. med. 7., 2, 897

and Lubran, M. (1965). Biochem. F., 95, 612.

Pollock, D. J.. and Coghill, N. F. (1966). Gut, 7, 333
Douthwaite, A. H., and Lintott, G. A. M. (1938). Lancet, 2, 1222 .

Gibbs, D. D. (1964). Gut, 5, 160.

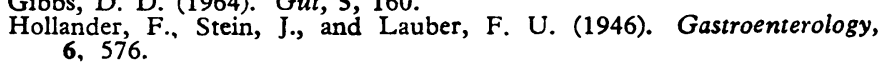

Hurst, A. P., and Lintott, G. A. M. (1939). Guy's Hosp. Rep., 89,

Kay, A. W. (1953). Brit. med. F., $2,77$.

Lipkin, M., Sherlock, P., and Bell, B. (1963). Gastroenterology, 46,

721.
Menguy, R., and Masters, Y. F. (1965). Surg. Gynec. Obstet., 120,

Muir, A. (1963a). In Salicylates, An International Symposium, edited by A. St. J. Dixon, B. K. Martin, M. J. H. Smith, and P. H. N. Wood, p. 187. London.

(1963b). Ibid., p. 230

- and Cossar, I. A. (1955). Brit. med. F., 2, 7.

Parry D. J., and Wood, P. H. N. (1963). In Salicylates, An International Symposium, edited by A. St. J. Dixon, B. K. Martin, M. J. H. Smith, and P. H. N. Wood, p. 233. London.

Smith, and P. H. N. Wood, P.

Pierson, R. N., jun., Holt, P. R., Wat (1961). Amer. \%. Med., 31, 259.

Stubbé, L. Th. F. L. (1958). Brit. med. F., 2, 1062.

Pietersen, J. H., and van Heulen, C. (1962). Ibid., 1, 675.

Weiss, A., Pitman, E. R., and Graham, E. C. (1961). Amer. F. Med. $31,266$.

Williams, A. W., Edwards, F., Lewis, T. H. C., and Coghill, N. F. (1957). Brit. med. ₹., 1, 372.

Winkelman, E. I., and Summerskill, W. H. J. (1961). Gastroenterology,

40, 56 . H. N. (1963). In Salicylates, An International Symposium, edited by A. St. J. Dixon, B. K. Martin, M. J. H. Smith, and P. H. N. Wood, p. 194 . London.

— and Dixon, A. St. J. (1966). Submitted for publication.

- Harvey-Smith. E. A., and Dixon, A. St. J. (1962). Brit. med. \%., 1,669 .

\title{
Haemodynamic Effects of Propranolol (Inderal) in Acute Myocardial Infarction
}

\author{
G. BAY,* M.D. ; P. LUND-LARSEN,* M.D. ; E. LORENTSEN,* M.D. ; E. SIVERTSSEN,* M.D.
}

Brit. med.7., 1967, 1, 141-143

The usefulness of $\beta$-adrenergic-blocking agents in various cardiac arrhythmias (Stock and Dale, 1963 ; Rowlands et al., 1965 ; Sloman et al., 1965) and in angina of effort (Alleyne et al., 1963 ; Hamer et al., 1964 ; Keelan, 1965) seems to be well established. A remarkable reduction in mortality in acute myocardial infarction in a group of patients treated with $\beta$ adrenergic-blocking drug compared with a control group is also reported (Snow, 1965).

The most serious clinical objection to cardiac $\beta$-adrenergicreceptor blockade is the depressing effect on myocardial contractility and the risk of precipitating heart failure (Stock and Dale, 1963 ; Prichard and Gillam, 1964). Experiments also indicate that $\beta$-adrenergic blockade decreases myocardial blood flow by abolition of sympathetic vasodilator tone and increasing the resistance to flow in the myocardial vascular bed (Parratt, 1965 ; Parratt and Grayson, 1966).

Before we decided to start a controlled clinical trial of the $\beta$-adrenergic-blocking drug propranolol (Inderal) in patients with acute myocardial infarction an investigation of the haemodynamic effects was carried out. The purpose of the investigation was to determine whether there might be any potential risks in the use of this drug in patients with myocardial infarction.

\section{Material and Methods}

Eight patients (seven males and one female) were studied in the acute stage of myocardial infarction. None of them had previously had myocardial infarction, heart failure, or pulmonary disease.

Their ages ranged from 51 to 71 (mean 59) years. In all patients the symptoms of acute myocardial infarction had started from 12 to 48 (mean 36 ) hours before the haemodynamic study was undertaken. The diagnoses were confirmed by serial E.C.G. and serum glutamic oxaloacetic transaminases (S.G.O.T.) determinations. Maximal S.G.O.T. ranged from 116 to 324 units. Five patients had anteroseptal and three had diaphragmatic localization of the infarction. One patient had atrial fibrillation, the other seven had sinus rhythm.

When the investigation was started the clinical condition of all patients was good. Three of them, however, did complain of slight retrosternal pains. The rectal temperatures ranged from 37 to $38.5^{\circ} \mathrm{C}$.

All patients were studied in the supine position. A PE-160 polyethylene catheter was inserted percutaneously through an antecubital vein into the right atrium and another polyethylene catheter was inserted through the right femoral artery into the terminal part of the aorta. The patients had a period of 15 minutes to relax after the application of the equipment.

Cardiac output and circulation time were determined 15 and 5 minutes before and 5, 15, and 30 minutes after intravenous injection of $5 \mathrm{mg}$. of propranolol. The injection was given slowly over a period of five minutes.

\footnotetext{
* Medical Department VIII, Ullevål Hospital, Oslo, Norway.
} 